\title{
POLLINATION SYNDROMES OF THE URBAN FLORA OF SANTO ANTONIO DE PÁDUA MUNICIPALITY, RIO DE JANEIRO STATE, BRAZIL
}

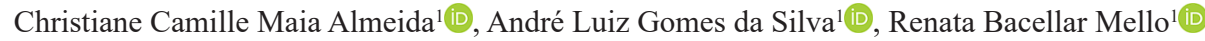 \\ ${ }^{1}$ Universidade Federal Fluminense, Instituto do Noroeste Fluminense de Educação Superior, Avenida João Jasbick, \\ s/no , Santo Antônio de Pádua CEP 28470 000, Rio de Janeiro, Brazil.
}

Corresponding author: algsilva@id.uff.br

\begin{abstract}
The current study aimed to describe the pollination syndromes of the tree species occurring in the urban area of Santo Antônio de Pádua, in the northwestern part of Rio de Janeiro state, southern Brazil. This municipality now has less than $4 \%$ of its original forest cover, resulting in a heavy decrease in faunal and floral diversity. Reported field observations were made over a one-year period between 2016 and 2017. In the study area, 31 species were identified in 14 families, with Fabaceae $(19 \%)$ having the largest number of species. Most studied species were exotic (75.6\%). The most frequent floral coloration was white $(29 \%)$, with nectar as the commonest floral reward $(47 \%)$ followed by nectar/pollen (40\%). Melittophilia was the most common pollination syndrome ( $71 \%$ ). Keywords: ecology urban, urban flora, floral biology
\end{abstract}

\section{SÍNDROMES DE POLINIZAÇÃO DA FLORA URBANA DO MUNICÍPIO DE SANTO ANTONIO DE PÁDUA - RJ}

\section{RESUMO}

O presente trabalho teve como objetivo descrever as síndromes de polinização das espécies arbóreas ocorrentes na área urbana do Município de Santo Antônio de Pádua, localizado no noroeste do estado do Rio de Janeiro. Atualmente este município apresenta menos de 4\% de sua cobertura original de mata, o que acaba contribuindo para a diminuição da diversidade de fauna e flora. As observações de campo foram desenvolvidas no período de um ano entre 2016 e 2017 . Na área de estudo foram identificadas 31 espécies distribuídas em 14 famílias, sendo Fabaceae (19\%) a mais representativa com o maior número de espécies. Foi constatado que a maioria das espécies estudadas era exótica $(75,6 \%)$. A coloração floral de maior representatividade foi branca $(29 \%)$ e a principal recompensa floral foi o néctar (47\%) seguido do conjunto néctar/pólen (40\%). A síndrome de polinização mais comum foi a de melitofilia (71\%).

Palavras-chave: Ecologia urbana. arborização urbana, biologia floral.

\section{INTRODUCTION}

Given that it brings the natural environment closer to the urban environment, urban floras can be considered an important element in spatial restructuring (BONONI, 2004). The environmental and social benefits of urban vegetation are many, and include: reduction of environmental impacts of urbanization, climate moderation, conservation of energy within houses and buildings, carbon dioxide absorption, improving water quality, control water flow and floods, noise level reduction, shelter and habitat for wildlife (RIBEIRO, 2009).

In addition to the important role of the urban flora in maintaining environmental quality in cities, it also plays a key role in maintaining the assemblage of natural pollinating agents attracted by these plants. In this context, it is importante to note that pollination is an essential phenomenon for maintaining biodiversity and one that is essential for plant species propagation.

Understanding the process of biotic pollination also involves an understanding of the floral attributes used by the pollinator. These resources need to satisfy at least one of the three main needs of pollinating animals: feeding, breeding or shelter (AGOSTINI et al. 2014). According to Faegri and van der Pijl (1979), all these floral attributes are linked to the various pollination syndromes (that is the set of characteristics of a flower that favors and/or attracts 
the visit of a particular pollinating agent), and so constitute an important guide to pollination ecology studies.

Each species or group of plants has specific morphological and physiological characteristics that attract particular types of pollinators. These characteristics have important implications not only for the relationship between the plant and its animal pollinators, but also for the reproduction of the plant species involved. According to Ramirez et al. (1990), the different floral types are related to the sensory development of pollinators, especially those concerning the ability to distinguish and memorize particular floral patterns.

The municipality of Santo Antônio de Pádua is located in northwestern Rio de Janeiro state. Its vegetation is composed of semi-humid forests and is part of the Mata Atlântica Biome (IBGE, 1992). However, most of the natural vegetation cover within the municipality has been lost to cattle ranching. More than $90 \%$ the original vegetation cover of the municipality has been lost (SOS Mata Atlântica Foundation, 2017), leaving only small fragments of natural forest at various stages of ecological succession, with less than $1 \%$ of their original vegetation cover (SILVA et al., 2009).

Afforestation is a very important component of urban ecology. In addition to its aesthetic and landscape function, it provides other innumerable benefits for both human and non-human populations (EMBRAPA 2009). Prominent among these is a capacity to bring humans closer to nature and the decrease of ecological and environmental impacts in the urban environment, so contributing to improvements in quality of life of the resident human population (SANTOS and TEIXEIRA, 2001).

However, urban afforestation must also fulfill the role of harboring and feeding the regional fauna. This is generally achieved by using a broad variety of species, as this positively influences local biodiversity, brings greater stability to food chains and minimizes the chance of pest and diseases vectors buildups. Thus, the urban flora is essential for the maintenance of biodiversity and ecosystem services, such as pollination since, in order for fruits and seeds to be formed plants in urban arborized areas, most plants require animals as pollinators and dispersers of their propagules.

Accordingly, the current study aimed to characterize the pollination syndromes of the urban plant assemblage in the municipality of Santo Antônio de Pádua and answering the following question: Is the urban flora of the region varied enough to attract a range pollinating animals?

\section{METHODOLOGY}

The current study took place between July 2016 and August 2017 in the urban area of the Santo Antônio de Pádua municipality headquarters, in northwestern Rio de Janeiro state. The municipality covers $669 \mathrm{~km}^{2}$ and has a mean altitude of 86 meters asl. Regional climate is hot and humid and classified as Aw according to Köppen (1948). The average annual temperature is $22.9^{\circ} \mathrm{C}$ and average annual rainfall $1234 \mathrm{~mm}$ (CLIMARTE- DATA.ORG, 2017).

Only cultivated trees and shrubs in the streets, avenues, alleys, squares and gardens were considered for this study. Monthly, fertile and nonfertile branches of these species were collected for later identification. In addition to the field visits to determine the plant species present, secondary data were also collected from the Municipal Environment Secretariat.

For each collected species the floral attributes such as shape, size, color and floral reward were recorded. To supplement visual observations, photographic records of the cataloged species were made.

Flower morphology was classified according to Faegri and van der Pijl (1979). Additionally, flowers were classified into six color categories: (1) white, (2) red (including orange), (3) greenish (including beige and cream), (4) yellow, (5) lilac (including blue and violet), and (6) pink (including magenta). Five classes of floral resources were considered: (1) pollen, (2) nectar, (3) oils, (4) resin and (5) pollen/ nectar (Faegri and Van Der Pijl, 1979).

In order to characterize the pollination syndromes, the species were collected in guilds according to the floral characteristics, in relation to their main pollination vector: Wind (Anemophilia), bees (Melittophilia), wasps (Vespophilia), butterflies and moths (Psychophilia), sphingids (Sphingophilia), flies (Myophilia) and beetles (Cantharophilia), hummingbirds (Ornithophilia) and bats (Chiropterophilia).

\section{RESULTS AND DISCUSSION}

Within the study area 31 woody urban plant species were recorded, in 29 genera, from 14 families (Table 1). The city has a great quantity of fruit-bearing trees, such as mangos, Malay apples, mulberries, star fruit, most notably on the margins of the Rio Pomba which cuts through the city.

The commonest families were Fabaceae 
(19.4\%), Bignoniaceae (12.9\%), Myrtaceae (12.9\%), Anacardiaceae (9.7\%), Lytraceae (6.5\%), Apocynaceae (6.5\%), Malvaceae (6.5\%), Moraceae $(6.5 \%)$. The majority of species were concentrated in eight families, with the remaining six species belonging to one family each. This form of richness by families has also found in other urban flora surveys, where Fabaceae is generally the most species-rich (CARVALHO et al. 2007, LOCASTRO and ANGELIS 2015, MOURA and SANTOS, 2009). Of the species recorded, $53.3 \%$ are foreign exotic, 33.4\% are from the north and northeast of Brazil, and only $13.3 \%$ are native to the Atlantic Forest. These data agree with those of Lorenzi (1998), who states that the majority of tree species cultivated in Brazilian cities are exotic. This is in spite of the fact that using native species in urban afforestation may favor climatic and soil adaptability, as well as increasing possibilities of producing healthy flowers and fruits, and as producing food for native animal species, and thus aiding overall native biota conservation.

Table 1. Characteristics of the urban flora of Santo Antônio de Pádua municipality headquarters, Rio de Janeiro State, Brazil.

\begin{tabular}{|c|c|c|c|}
\hline FAMILY & SPECIES & $\begin{array}{l}\text { POPULAR NAME } \\
\text { (Brazilian, English) }\end{array}$ & NATURAL OCCURRENCE \\
\hline \multirow{3}{*}{ Anacardiaceae } & Anacardium occidentale L. & $\begin{array}{l}\text { Cajueiro, } \\
\text { cashew }\end{array}$ & Brazil (North/Northeast) \\
\hline & Mangifera indica L. & $\begin{array}{l}\text { Mangueira, } \\
\text { mango. }\end{array}$ & India \\
\hline & Spondias mombin L. & $\begin{array}{l}\text { Cajazeiro, } \\
\text { sour plum }\end{array}$ & Brazil (Mata Atlântica) \\
\hline \multirow[t]{2}{*}{ Apocynaceae } & Nerium oleander L. & Espirradeira, oleander & $\begin{array}{l}\text { Africa, Asia Minor and } \\
\text { Mediterranean. }\end{array}$ \\
\hline & Plumeria rubra L. & Jasmin manga, plumeria & Tropical America \\
\hline Arecaceae & Roystonea oleracea Cook. & $\begin{array}{l}\text { Palmeira real, royal } \\
\text { palm }\end{array}$ & Carribbean \\
\hline \multirow{4}{*}{ Bignoniaceae } & $\begin{array}{l}\text { Spathodea campanulata } \\
\text { P.Beauv. }\end{array}$ & $\begin{array}{l}\text { Espatódea, } \\
\text { African tulip tree }\end{array}$ & Africa \\
\hline & $\begin{array}{l}\text { Tabebuia ipe (Mart. ex K. } \\
\text { Schum.) Standl. }\end{array}$ & $\begin{array}{l}\text { Ipê-rosa, } \\
\text { princess tree }\end{array}$ & Brazil (Mata Atlântica) \\
\hline & $\begin{array}{l}\text { Handroanthus chrysotricha } \\
\text { (Mart. Ex Dc.) Mattos }\end{array}$ & $\begin{array}{l}\text { Ipê-amarelo } \\
\text { Epay,ipe }\end{array}$ & Brazil (Mata Atlântica) \\
\hline & $\begin{array}{l}\text { Tecoma stans (L.) Juss. ex } \\
\text { Kunth }\end{array}$ & $\begin{array}{l}\text { Ipê-jardim } \\
\text { vellow trumpetbush }\end{array}$ & Mexico to Peru \\
\hline Chrysobalanaceae & Licania tomentosa Benth. & $\begin{array}{l}\text { Oiti, } \\
\text { gopher apple/false } \\
\text { zapota }\end{array}$ & Brazil (North/Northeast) \\
\hline Combretaceae & Terminalia catappa $\mathrm{L}$. & $\begin{array}{l}\text { Amendoeira } \\
\text { Indian almond/sea } \\
\text { almond }\end{array}$ & Tropical Asia \\
\hline \multirow{5}{*}{ Fabaceae } & $\begin{array}{l}\text { Clitoria fairchildiana Howard } \\
\text { Delonix regia (Bojer ex } \\
\text { Hook.) Raf. }\end{array}$ & $\begin{array}{l}\text { Sombreiro, sombreiro } \\
\text { Flamboyant } \\
\text { flamboyant }\end{array}$ & $\begin{array}{l}\text { Brazil (Amazônia) } \\
\text { Madagascar }\end{array}$ \\
\hline & Inga edulis Mart. & $\begin{array}{l}\text { Ingá, } \\
\text { Inga }\end{array}$ & Brazil (Mata Atlântica) \\
\hline & Bauhinia variegata $\mathrm{L}$. & $\begin{array}{l}\text { Pata de vaca, } \\
\text { orchid tree/camels foot } \\
\text { tree }\end{array}$ & Asia \\
\hline & $\begin{array}{l}\text { Caesalpinia leiostachya } \\
\text { (Benth.) Hook }\end{array}$ & $\begin{array}{l}\text { Pau-ferro, } \\
\text { iron wood }\end{array}$ & Brazil (Mata Atlântica) \\
\hline & $\begin{array}{l}\text { Albizia lebbeck. (Benth) } \\
\text { Barneby \& Grimes }\end{array}$ & $\begin{array}{l}\text { Angico, } \\
\text { flea tree }\end{array}$ & Tropical Asia \\
\hline \multirow{2}{*}{ Lythraceae } & Lagerstroemia indica $\mathrm{L}$. & $\begin{array}{l}\text { Extremosa, } \\
\text { crepe myrtle }\end{array}$ & Asia \\
\hline & Punica granatum L. & $\begin{array}{l}\text { Romã, } \\
\text { pomeganite }\end{array}$ & Iran \\
\hline Malpighiaceae & Malpighia emarginata DC & $\begin{array}{l}\text { Aceroleira, } \\
\text { acerola/Barbados cherry }\end{array}$ & $\begin{array}{l}\text { Central America \& northern } \\
\text { South America }\end{array}$ \\
\hline \multirow{2}{*}{ Malvaceae } & Ceiba speciosa (St. Hil.) Rav. & $\begin{array}{l}\text { Paineira, } \\
\text { kapok tree/silk floss tree }\end{array}$ & Brazil (Mata Atlântica) \\
\hline & Pachira aquatica Aubl. & $\begin{array}{l}\text { Falso cacau } \\
\text { malabar chestnut }\end{array}$ & Brazil (North/Northeast) \\
\hline
\end{tabular}




\begin{tabular}{|c|c|c|c|}
\hline FAMILY & SPECIES & $\begin{array}{l}\text { POPULAR NAME } \\
\text { (Brazilian, English) }\end{array}$ & NATURAL OCCURRENCE \\
\hline \multirow{2}{*}{ Moraceae } & Ficus.sp & $\begin{array}{l}\text { Figueira } \\
\text { fig }\end{array}$ & - \\
\hline & Morus nigra L. & $\begin{array}{l}\text { Amoreira, } \\
\text { black mulberry }\end{array}$ & Asia \\
\hline \multirow{4}{*}{ Myrtaceae } & Eugenia uniflora L. & $\begin{array}{l}\text { Pitangueira, } \\
\text { pitanga/Brazilian cherry }\end{array}$ & Brazil (Mata Atlântica) \\
\hline & Psidium guajava L. & $\begin{array}{l}\text { Goiabeira } \\
\text { guava }\end{array}$ & Brazil (Mata Atlântica) \\
\hline & Syzygium cumini (L) Skeels & $\begin{array}{l}\text { Jambolão, } \\
\text { java plum }\end{array}$ & Siri Lanka \& India \\
\hline & $\begin{array}{l}\text { Syzygium malaccense (L.) } \\
\text { Merr.\& L.M Perry }\end{array}$ & $\begin{array}{l}\text { Jambo vermelho } \\
\text { malay apple, sugar apple }\end{array}$ & Polynesia \\
\hline Oleaceae & Ligustrum japonicum Thunb. & $\begin{array}{l}\text { Ligustro, } \\
\text { Japanese privet }\end{array}$ & Japan \& Korea \\
\hline Oxilidaceae & Averrhoa carambola L. & $\begin{array}{l}\text { Carambola, } \\
\text { star fruit }\end{array}$ & Asia and Indonesia \\
\hline
\end{tabular}

Seven pollination syndromes were identified for the recorded species (Figure 1). The least common pollination syndrome was anemophilia, found only in Morus nigra, while the most common was melittophilia, identified in around $70 \%$ of the species recorded. Kinoshita et al. (2005), Yamamoto et al. (2006) and dos Santos et al. (2009) also found that melittophilia is the most common syndrome in natural areas of the Atlantic Forest. Similar proportion have been reported from Cerrado (SILBERBAUERGOTTSBERGER AND GOTTSBERGER, 1988), Restinga (ORMOND et al.,, 1993), Caatinga (Leal et al. 2006), and Amazon forest (REIS et al., 2012) environments. Thus, it appears that melittophilia is the most common pollination syndrome in practically all natural environments in Brazil.

Ornithophyly was present in $9.7 \%$ of the recorded species (Figure 1), with the main pollinating species being hummingbirds. Bat-pollinated plants pollinated constituted $3.2 \%$ of recorded species (Figure 1), such species generally have strongly-scented, night-opening flowers (Table 2). Psychophilia occurred in 6.4\% of species (Figure 1). In all Brazilian ecosystems the interactions between plants and butterflies and moths is complex.

Considering floral characteristics, plants with white-petaled flowers were most common $(29 \%)$, followed by pink (26\%), greenish (22\%), red (10\%), and yellow (3\%). Accordingly, there was a much higher proportion of species $(61 \%)$ with pale flowers (including yellow, green and white) than stronglycolored ones (39\%: red, pink and lilac). Interestingly, although plant choice must to some extent reflect horticultural contingencies and human preferences, similar proportions have been found in natural regional plant assemblages in Restingas (ORMOND et al. 1993), though a predominance of strong colors was recorded in Caatinga by Leal et al. (2006).

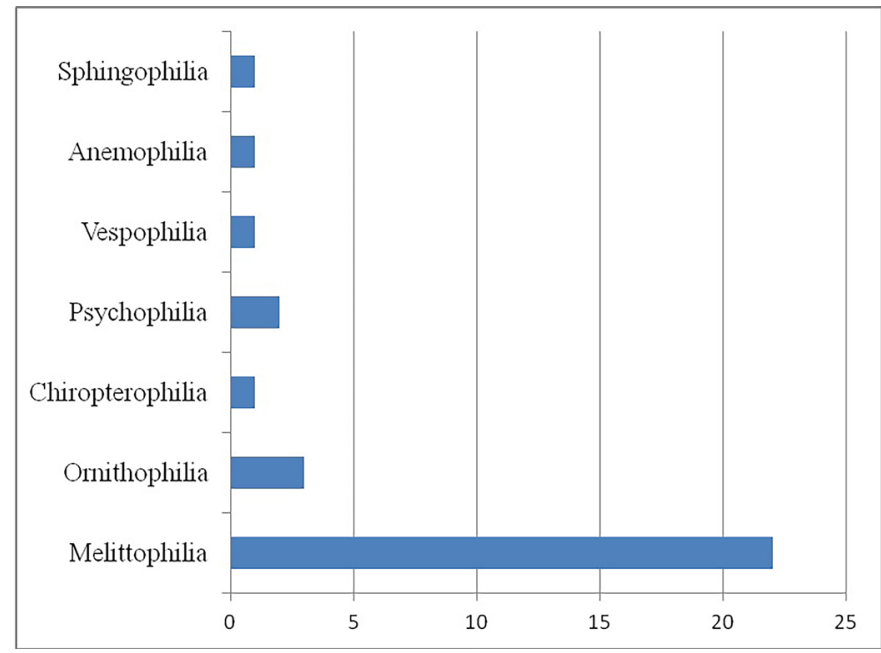

Figure 1- Percentage of pollination syndromes of tree and shrub species recorded in the urban area of Santo Antonio de Pádua municipality headquarters, Rio de Janeiro State, Brazil. 
Table 2. Pollination characteristics and syndromes of shrub and tree species in the urban area of Santo Antônio de Pádua municipality, Rio de Janeiro State, Brazil

\begin{tabular}{|c|c|c|c|c|c|}
\hline Species & $\begin{array}{c}\text { Anthesis } \\
\text { period }\end{array}$ & $\begin{array}{l}\text { Flower } \\
\text { color }\end{array}$ & $\begin{array}{c}\text { Floral } \\
\text { attract-ant }\end{array}$ & $\begin{array}{c}\text { Floral } \\
\text { resource }\end{array}$ & $\begin{array}{c}\text { Pollination } \\
\text { syndrome }\end{array}$ \\
\hline $\begin{array}{l}\text { Albizia lebbeck. (Benth) } \\
\text { Barneby \& Grimes }\end{array}$ & Day & White & Scent & Nectar Pollen & Melllitofilia \\
\hline Anacardium occidentale L. & Day & Pink & Scent & Nectar Pollen & Mellitophilia \\
\hline Averrhoa carambola $\mathrm{L}$. & Day & Pink & Color, Scent & Nectar & Mellitophilia \\
\hline Bauhinia variegata $\mathrm{L}$. & Day & White/Pink & Scent & Nectar & Mellitophilia \\
\hline $\begin{array}{l}\text { Caesalpinia leiostachya } \\
\text { (Benth.) Hook }\end{array}$ & Day & Yellow & Color & Nectar Pollen & Mellitophilia \\
\hline Ceiba speciosa (St. Hil.) Rav. & Day & Pink & Color & Nectar & Ornitofilia \\
\hline Clitoria fairchildiana Howard & Day & Liliac & Color & Nectar Pollen & Mellitophilia \\
\hline $\begin{array}{l}\text { Delonix regia (Bojer ex Hook.) } \\
\text { Raf. }\end{array}$ & Day & Red & Color & Nectar Pollen & Ornithophilia \\
\hline Eugenia uniflora $\mathrm{L}$. & Day & White & Scent & Pollen & Mellitophilia \\
\hline Ficus.sp & Day & Greenish & Scent & $\begin{array}{l}\text { Ovoposition } \\
\text { site }\end{array}$ & Vespophilia \\
\hline $\begin{array}{l}\text { Handroanthus chrysotricha } \\
\text { (Mart. Ex Dc.) Mattos }\end{array}$ & Day & Yellow & Scent & Nectar & Mellitophilia \\
\hline Inga edulis Mart. & Night & White & Scent & Nectar & Sphingophilia \\
\hline Lagerstroemia indica $\mathrm{L}$. & Day & Pink & Color & Nectar Pollen & Mellitophilia \\
\hline Licania tomentosa Benth. & Day & Greenish & Scent & Nectar Pollen & Mellitophilia \\
\hline Ligustrum japonicum Thunb. & Day & Greenish & Scent & Nectar & Mellitophilia \\
\hline Malpighia emarginata DC. & Day & Pink & Scent & Nectar Oils & Mellitophilia \\
\hline Mangifera indica $\mathrm{L}$. & Day & Greenish & Scent & Nectar Pollen & Mellitophilia \\
\hline Morus nigra L. & Day & Green & - & - & Anemophilia \\
\hline Nerium oleander L. & Day & Pink & Scent & Nectar & Psychcophilia \\
\hline Pachira aquatica Aubl. & Night & Greenish & Scent & Nectar & Chiropterophilia \\
\hline Plumeria rubra $\mathrm{L}$. & Day & White & Scent & Nectar & Psycophilia \\
\hline Psidium guajava $\mathrm{L}$. & Day & White & Scent & Nectar Pollen & Mellitophilia \\
\hline Punica granatum $\mathrm{L}$. & Day & Red & Scent & Nectar Pollen & Mellitophilia \\
\hline Roystonea oleracea Cook. & Day & White & Scent & Pollen & Mellitophilia \\
\hline $\begin{array}{l}\text { Spathodea campanulata } \\
\text { P.Beauv. }\end{array}$ & Day & Red & Scent & Nectar & Ornithophilia \\
\hline Spondias mombin L. & Day & White & Scent & Nectar Pollen & Mellitophilia \\
\hline Syzygium cumini (L.) Skeels & Day & Greenish & Scent & Nectar Pollen & Mellitophilia \\
\hline $\begin{array}{l}\text { Syzygium malaccense (L.) } \\
\text { Merr. \& LM Perry }\end{array}$ & Day & Pink & Color & Nectar & Mellitophilia \\
\hline $\begin{array}{l}\text { Tabebuia ipe (Mart. ex K. } \\
\text { Schum.) Standl. }\end{array}$ & Day & Pink & Color & Nectar & Mellitophilia \\
\hline $\begin{array}{l}\text { Tecoma stans (L.) Juss. ex } \\
\text { Kunth }\end{array}$ & Day & Yellow & Color & Nectar & Mellitophilia \\
\hline Terminalia catappa $\mathrm{L}$. & Day & White & Scent & Nectar & Mellitophilia \\
\hline
\end{tabular}


Flower color has a direct relation with the type of vision that visiting animals possess. Varassin and Amaral-Neto (2014) suggest that the visual signals produced by flowers were evolutionarily fundamental for the establishment of such interactions.

Nectar was the most commonly used plant resource $(47 \%)$, followed by nectar/pollen (40\%), pollen grains $(7 \%)$, oils (3\%) and oviposition site (3\%). Similar results have been found in other studies of urban plant community resource profiles, including Silberbauer-Gottsberger and Gottsberger (1988), Ramirez et al. (1990), Ormond et al. (1993), Oliveira and Gibs (2000) and Leal et al. (2006). Floral nectar has an intimate association with the biology of a plant pollinators, since it is a food rich in sugars that provides energy for it's activity. Although, many nectar sugar concentrations seem to be adjusted to ensure that pollinators must return fairly soon to the so - thus guaranteeing pollen grains transfer. Accordingly, nectar is a food sought by a wide variety of insects and birds, as well as some mammals (AGOSTINI et al., 2014). Pollen grains, each of which acts as a vehicle for the male gamete, also form part of the diet of several groups of insects, including beetles and bees among others, as well as birds and mammals. The analysis on the chemical constitution of pollen grains show they contain mainly protein, as well as lipids, starches and sugars (AGOSTINI et al., 2014).

\section{FINAL CONSIDERATIONS}

The study allowed a quantitative analysis of the composition of the urban flora in the municipality of Santo Antônio de Pádua, and the identification of the most common pollination syndromes. Most of the species present were exotic, and so may be highly beneficial to local wildlife. As already indicated native plants have a high potential and adaptability to be used in the urban arborization, which brings benefits to this fauna.

Melittophilia was the most common pollination syndrome and species producing nectar as a floral resource were also the most common. Finally, a plea is made for the adoption of strong environmental considerations when considering the species composition of urban floral plantings, since, especially in areas where deforestation is extensive, such plants will be responsible for the maintenance and conservation of many of the pollinating animals present in the area. Managed properly urban planting has the potential to significantly attract the local pollinating fauna, especially in areas where much of its original vegetation is now lost. For urban plantings to have maximum conservation value to the local pollinator assemblage, it is necessary that some measures be taken, such as planting a greater variety of native species and their proper management, as well as studies of which non-native species are most attractive to native pollinators, and planting to guarantee resource availability throughout the year.

\section{REFERENCES}

AGOSTINI, K., LOPES, A.V., MACHADO I.C.S. 2014. Recursos florais. In: Rech AR, Agostini KO, Oliveira PE, AM, Machado ICS. Biologia da polinização. $1^{\mathrm{a}}$ ed. Rio de Janeiro: Ed. Projeto Cultural. 2014. cap 6. p. 129-150.

BONONI, V.L.R. 2004. Curso de Gestão Ambiental. Controle Ambiental de Áreas Verdes. Barueri-SP: Manoli.

CARVALHO, G.M., ROQUE, N., GUEDES, M.L.S. 2007. Levantamento das Espécies Arbóreas da Universidade Federal da Bahia, Salvador, Bahia. Sitientibus- Série Ciências Biológicas, 7: 377-387.

CLIMART-DATA.ORG. 2017. Dados climáticos para cidades mundiais. Disponível em $<$ https:// pt.climate-data.org/>.

EMBRAPA (Empresa Brasileira de pesquisa, agropecuária). 2017. Disponível em <http:// www.cnpf.embrapa.br/publica/boletim/boletarqv/ boletim18_19/baggio.pdf $>$.

FAEGRI, K.; VAN DER PILJ, L. 1979. The principles of pollination ecology. $3^{\circ}$ ed. Oxford, Inglaterra.

FUNDAÇÃO SOS MATAATLÂNTICA. Disponível em $<$ http://aquitemmata.org.br/\#/busca/rj/State $\% 20$ of $\% 20$ Rio $\% 20 \mathrm{de} \% 20$ Janeiro/Santo $\% 20 \mathrm{Ant} \%$ C3\%B4nio\%20de\%20P\%C3\%A1dua $>$.

IBGE (Instituto brasileiro de Geografia e Estatística). 2017. cobertura vegetal. Disponível em: http://www. ibge.gov.br.

KINOSHITA, L.S.; TORRES, R.B.; MARTINS, E.R.F.; SPINELLI, T.; AHN, Y.J.; CONSTÂNCIO, S,S. 2005. Composição florística e síndromes de polinização e dispersão da Mata do Sítio São Francisco, Campinas, SP, Brasil. Acta Botanica Brasilica, 2(20): 313-327.

LEAL, F.C.; LOPES, A.V.; MACHADO, I.C. 2006. Polinização por beija-flores em uma área de caatinga no Município de Floresta, Pernambuco, Nordeste 
do Brasil. Revista Brasileira de Botânica, 29(3): 379-389.

LOCASTRO, J.K.; ANGELIS, B.L.D. 2015. Diagnóstico quali-quantitativo da arborização urbana em duas avenidas do município de Maringá - PR. Revista Eletrônica em Gestão, Educação e Tecnologia Ambiental, 19: 248-255.

LORENZI, H. 1998. Árvores brasileiras. São Paulo: Plantarum, vol. 1.

MOURA, T.A.; SANTOS, V.L.L.V. 2009. Levantamento quali-quantitativo de espécies arbóreas e arbustivas na arborização viária urbana dos bairros centro e centro norte, Várzea Grande, Mato Grosso, Brasil. Revista da Sociedade Brasileira de Arborização Urbana, 4: 97-117.

OLIVEIRA, A.A.M.; COSTA, D.D.; SALGADO, D.P.; MOURA, I.O.; TEIXEIRA, K.A.; SANTOS, L.L.; CATEIN, S,M. 2002. Plano de Gestão das Unidades de Conservação Estaduais em Goiás Proposta Metodológica e Executiva. Documento do Departamento de Áreas Protegidas para a Gestão das Unidades de Conservação Estaduais. Goiânia: Agência Ambiental de Goiás.

OLIVEIRA, R.; DUARTE, J.A.J.; RECH, A.R.; AVILA, R.S. 2014. Polinização por Lepidoptera. In: Rech A, Agostini K, Machado I, Oliveira PEM. (Org.). Biologia da Polinização. $1^{\mathrm{a}}$ ed. Rio de Janeiro: Editora Projeto Cultural.

ORMOND, W.T.; PINHEIRO, M.C.B.; LIMA, H.A.; CORREIA, M.C.R.; PIMENTA, M.L. 1993. Estudo das recompensas florais das plantas da restinga de Maricá - Itaipuaçu, RJ. I - Nectaríferas. Bradea, 6: 179-195.

PEREIRA, G.A.; MONTEIRO, C.S.; CAMPELO, M.A.; MEDEIROS, C. 2005. O uso de espécies vegetais, como instrumento de biodiversidade da avifauna silvestre, na arborização pública: o caso do Recife. Atualidades Ornitológicas, 125: 10-18.

RAMIREZ, N.; GIL, C.; HOKCHE, O.; SERES, A.;
BRITO, Y. 1990. Biologia floral de uma comunidade arbustiva tropical em la Guayana Venezolana. Annals of the Missouri Botanical Garden, 77: 383-397.

REIS, S.; MOHR, A.; GOMES, L.; SILVA,A.C.S.M.F.; LENZA, E. 2012. Síndrome de Polinização e dispersão de Espécies Lenhosas em um fragmento de Cerrado sentido Restrito na transição Cerrado- Floresta Amazônica. Heringeriana, 6(2): 28-41.

RIBEIRO, F.A.B.S. 2009. Arborização Urbana em Uberlândia: Percepção da População. Revista Católica, 1(1): 24-237.

SANTOS, A.B.; TEIXEIRA, I.F. 2001. Análise Qualitativa da Arborização de Ruas do Conjunto Habitacional Tancredo Neves, Santa Maria - RS. Ciência Florestal, 9(2): 9-21.

SANTOS, N.R.Z.; TEIXEIRA, I.F. 2001. Arborização de vias públicas: ambiente $x$ vegetação. Instituto Souza Cruz, SEGAWA, Hugo. Ao Amor do Público: Jardins no Brasil. São Paulo: Studio Nobel.

S IL B ER B A U ER - G O T T S B ER GER, I ; GOTTSBERGER, G. 1988. A polinização de plantas do cerrado. Revista Brasileira de Biologia, 48(4): 651-663.

SILVA, M.M.; SOUZA, R.O.; ANDRADE, G.T. 2009. Aspectos dos Problemas Ambientais da Região Noroeste do Estado do Rio de Janeiro: Um estado de caso. XII Do Encuentro de Geógrafos de América Latina, Montevideo. Caminando En Una América Latnaen Transformación. Anais. Montevideo: Imprenta Gega, 3: 1-10.

VARASSIN, I.G.; AMARAL NETO, L.P. ATRATIVOS. 2014. In: Rech A, Agostini K, Machado I, Oliveira PEM. (Org.). Biologia da Polinização. $1^{\mathrm{a}}$ ed. Rio de Janeiro: Editora Projeto Cultural.

YAMAMOTO, L.F., KINOSHITA, L.S.; MARTINS, F.R. 2006. Síndromes de polinização e de dispersão em fragmentos da Floresta Estacional Semidecídua Montana, SP, Brasil. Acta Bototanica Brasilica, 21(3): 553-573. 